Jeszenszky, Géza. "The Controversy About 1944 in Hungary and the Escape of Budapest's Jews from Deportation. A Response." Hungarian Cultural Studies. e-Journal of the American Hungarian Educators Association, Volume 13 (2020) DOI: 10.5195/ahea.2020.388

\title{
The Controversy About 1944 in Hungary and the Escape of Budapest's Jews from Deportation. A Response.
}

\section{Géza Jeszenszky}

\begin{abstract}
The purpose of this Note is to clarify the interpretation of the volume, July 1944: Deportation of the Jews of Budapest Foiled (Reno, NV: Helena History Press, 2018), put forth by Peter Pastor in his book review, "A New Historical Myth from Hungary: The Legend of Colonel Ferenc Koszorús as the Wartime Saviour of the Jews of Budapest," that was published in the 2019 issue of Hungarian Cultural Studies. Rather than making any attempt to remove or lessen blame for the acts committed following the German occupation of Hungary in March 1944, this collection of studies aims to shed light on whether Regent Horthy's order to Colonel Ferenc Koszorús prevented the deportation of the remaining, nearly 300,000 Hungarian Jews who lived (or were just hiding) in Budapest.
\end{abstract}

Keywords: Hungary, World War II, Hungarian Soviet Republic, Regent Miklós Horthy, Miklós Kállay, Colonel Ferenc Koszorús, Budapest, German occupation of Hungary, Quislinggovernment, Holocaust, deportations, war criminals, László Baky, F.J. Montgomery

Biography: Géza Jeszenszky is a Hungarian historian and politician. He has completed degrees in history, English, and library studies at Eötvös Loránd University, Budapest, where he also attained his Ph.D. Following his work as a schoolteacher and librarian, he became a university professor at today's Corvinus University of Budapest after 1976. His more recent publications include Post-Communist Europe and Its National/Ethnic Problems (Budapest, 2005, 2009) and Kísérlet a trianoni trauma orvoslására. Magyarország szomszédsági politikája a rendszerváltozás éveiben ['Attempting to Heal the Trauma of Trianon: Hungary's Political Relations With Its Regional Neighbors in the First Years of Democracy'], a personal account of Hungary's relations with its neighbours during the years of the regime change (Budapest, 2016). His work, Lost Prestige: The Changing Image of Hungary in Britain, 18941918, was published in Hungarian in 1986 and 1994 and is appearing in English in 2020. Following the nation's political transformation, he acted as Hungary's foreign minister (1990-94) and ambassador first to the United States (1998-2002), then to Norway and Iceland (2011-14).jgeza1941@gmail.com

In the last issue of this e-journal, Peter Pastor wrote what looks like a review article about the book edited and partly written by me, July 1944: Deportation of the Jews of Budapest Foiled. He must have missed or misread much of my earlier and more recent writings and pronouncements to impute upon me the intention of diminishing or denying the responsibility of Regent Horthy and so many other Hungarians for the Holocaust of roughly half-a-million Jews, who were Hungarian both in their language and identity. The aim of the book was the very opposite: to shed light on a little-known controversy connected to this enormous tragedy. Was it 
Jeszenszky, Géza. “The Controversy About 1944 in Hungary and the Escape of Budapest's Jews from Deportation. A Response." Hungarian Cultural Studies. e-Journal of the American Hungarian Educators Association, Volume 13 (2020) DOI: 10.5195/ahea.2020.388

really the order of Horthy issued to a unit of the Hungarian army which prevented the deportation of the remaining, nearly 300,000 Hungarian Jews who lived (or were just hiding) in Budapest? Their temporary escape leads to another question: was the Regent an accomplice in the murder of a half-million Hungarian Jews, yet also the savior of those who remained?

The basic facts cannot be disputed. Colonel Ferenc Koszorús used the $1^{\text {st }}$ Hungarian Armoured Division under his command to force the removal from the capital of the gendarmerie, a police unit that was loyal to the pro-Nazi puppet government and ready to carry out the deportation of Jews from Budapest. Following his stand at the crown council meeting held on June 26, 1944, Horthy, under international pressure and also gleaning from the Auschwitz Protocol what was in store for the deported Hungarian nationals, ordered the end of deportations. Rumors had spread throughout the city - even reaching the Castle, where the head of state lived - that the pro-Nazi and rabidly anti-Semitic State Secretary Baky was planning a coup to remove the Regent and thereby continue the deportations. Having received an order from Horthy, Koszorús entered Budapest with his troops and sent a courier to Baky, threatening him with military action unless the gendarmerie were withdrawn. Baky had no alternative but to comply. This action foiled the coup (if it had indeed really been in the making) and, what is more important, the continuation of the deportations. The Jews of Budapest were thus temporarily saved, and Raoul Wallenberg and others were able to help many to survive the war until the Soviet army liberated and occupied Budapest.

In a long article published in the June 21, 2019 issue of the weekly, Élet és Irodalom ['Life and Literature'], the Hungarian historian, László Karsai, questioned the scholarly credentials of the book's editor and some of its other authors by also charging it of attempting to acquit Horthy from responsibility for the murder of a half million of his fellow citizens. My answer was followed by Karsai's rejoinder and my response. Most probably not unconnected to Karsai's reaction to the book, came the Hungarian-born Peter Pastor with his even harsher article in the 2019 issue of Hungarian Cultural Studies. Since Pastor questioned the intentions and even the academic standard of the entire book, I addressed a detailed rebuttal to my fellow authors and published an essay on the controversy in the bimonthly Hungarian Review (http://www.hungarianreview.com/article/20190921_the_controversy_about_july_1944 10,).

July 1944 does not aim to present the story of Hungary's involvement in the Second World War or just of the Hungarian Holocaust. Yet Pastor's aim is more than just to discredit my collaborators and myself. It is to maximize and overstate the guilt Hungary must bear for participating in the Second World War, when it was allied to Germany. He is not alone in lumping together the conduct of Hungary before its Nazi occupation in March 1944 and the crimes committed by the puppet government and its agents, imposed upon the country following this event. All the authors of the book as well as Pastor know that in the 1930s Hungary as well as many other European countries had little choice: either accept Hitler's growing influence over their country or resist it at the price of war. Hungary had the additional predicament: its justified claim for border revision was only supported by Italy and Germany. Nevertheless, in August 1938 Hungary (and the Regent personally) turned down Hitler's offer to attack Czechoslovakia with German help and thus annex Slovakia, a territory which had been a part of the Kingdom of Hungary until 1919. In July 1939, Hungary refused to support the Nazi plan to attack Poland; in September Hungary accepted well over a hundred thousand refugees from its traditional friend, now prostrate. 
Jeszenszky, Géza. “The Controversy About 1944 in Hungary and the Escape of Budapest's Jews from Deportation. A Response." Hungarian Cultural Studies. e-Journal of the American Hungarian Educators Association, Volume 13 (2020) DOI: 10.5195/ahea.2020.388

Subsequently, wedged between the devil and the deep sea (i.e., either collaborate with Nazi Germany or share the fate of Poland), Horthy and most of the Hungarian public opted for the former, a decision also motivated by the attractive, territorial rewards that went with that. (This was called a Faustian pact by Bryan Cartledge in his masterly history of Hungary, The Will to Survive.) Joining the World War on the side of the Axis was an obvious blunder (as I call it in my essay), even a crime, but one that had its mitigating circumstances. Recognizing this enormous mistake by March 1942, Horthy and his trusted new prime minister, Miklós Kállay, tried to approach the British and the Americans to make them understand Hungary's precarious position and offer to break away from Germany as soon as such as step would be militarily possible. No one described Hungary's participation in the war better than F.J. Montgomery, Roosevelt's former envoy to Hungary, who referred to it in his memoirs as "the unwilling satellite" (Montgomery 1947). There is no denying, however, that a large part of Hungary's public was ignorant, misled or just blindly pro-German, while additionally motivated by a justified fear of communism and the Soviet Union. On this account as well, Hungary's pro-Ally political and economic elite had to move carefully, a caution that was even more necessary due to the investigating eyes of German diplomats and spies.

All was changed by the German occupation of Hungary on March 19, 1944. The puppet government installed by Germany and the majority of the functioning state administration (including the army, police and the gendarmerie) concealed the fact that Hungary was no longer sovereign and master of its own fate. The terrible crimes committed after the occupation, the Hungarian Holocaust, belong to the blackest pages of Hungarian history. Most of those who participated in these events were punished and deserve the contempt of posterity. When contributing to July 1944, those of the authors who are still among the living certainly did not try to reduce the responsibility either of the guilty or of those who made decisions which turned out to be fatal. An honest historian cannot and should not make rushed judgments. We all have to bear in mind how trying those times were.

Now let me answer Pastor's charges and misrepresentations one by one. Even if Pastor had not known me for decades, had not read my historical works and was not aware of my past and present political views, it would still be a misreading of my Introduction and essay on Hungary's wartime foreign policy to suggest that the book has anything to do with present-day Hungarian politics. It is known in Hungary that nothing is further from me than an attempt "to advance the rehabilitation campaign" allegedly conducted by the Orbán government as a means of whitewashing Horthy and acquitting those roughly 200,000 Hungarian collaborators in the Quisling-type of government from their responsibility for the crimes committed following the country's military occupation. An objective reading of the book would prove that - like any scholarly work - it is open to criticism but remains an honest attempt to answer very difficult historical and moral questions in connection to the tragic events that took place in Hungary in 1944.

The first sign of Pastor's malice is exhibited in the statement that, "This book is a compilation of essays by authors who were previously published elsewhere." Not that it would be improper or superfluous to republish studies which have appeared in different works at different times, but in fact four out of eight pieces in this book were written specifically for the present volume; two are translations from Hungarian originals. The selected documents in the Appendix have been translated from German originals that had previously only been published 
Jeszenszky, Géza. “The Controversy About 1944 in Hungary and the Escape of Budapest's Jews from Deportation. A Response." Hungarian Cultural Studies. e-Journal of the American Hungarian Educators Association, Volume 13 (2020) DOI: 10.5195/ahea.2020.388

in Hungarian. It is the reviewer's mistaken assertion that the "main focus of the book is on Ferenc Koszorús.” As I stated in my Introduction, the main purpose of this collection was to offer an answer to several historical controversies.

Should Horthy be praised for defying the Nazis in July 1944, or condemned for not having prevented the crime earlier? Or there is the larger controversy: as a result of the German occupation did Hungarian sovereignty come to an end and so the responsibility for the ensuing horrors rests mainly or entirely with Nazi Germany? Is the whole Hungarian nation guilty because of the active collaboration by many Hungarians? As historians, my colleagues and I are committed neither to the whitewashing nor to the blackening of the record. The subject is about the deliberate murder of more than a half-million innocent people. Here the attempt for historical accuracy runs parallel to understanding the sentiments of the survivors, those related to the victims, and indeed of all decent people. The present collective volume cannot answer all the historical questions and settle the debates; the purpose is only to show what really happened in the crucial days in early July (9).

Clearly the focus in the volume was not to what extent Colonel Koszorús was a hero, but rather on how and why Horthy, the Regent, could stop the deportations in July if he could not or did not do so when the Hungarian puppet government started them on May 15.

I cannot but quote again from my Introduction, where I stated my agreement with the judgment of the late Randolph Braham and several other authors, including that of the late, distinguished Hungarian historian, György Ránki, who at the age of fourteen was himself a survivor of Auschwitz and wrote about the Holocaust in Hungary. I wrote the following:

The new, blindly pro-Nazi members of the typically puppet-government imposed on the country betrayed their Jewish compatriots and surrendered them to Nazi Germany.... The Sztójay government, the Hungarian civil service and the Hungarian gendarmerie facilitated the deportations with decrees and with their merciless action.... Those who were responsible for taking Hungary recklessly into the war, and who issued the orders for the deportations and carried those orders out, were tried in Hungary after the war. Between 1945 and 1949, 59, 429 persons were tried by specially created 'people's courts': 26,997 were found guilty. 477 were sentenced to death, and actually 189 were executed, including four heads of government and several ministers. Compare that to relevant figures in other countries occupied by Nazi Germany, or even to Germany itself - Hungary cannot be charged to have been lenient towards its war criminals. Those were indeed traitors to their nation, as they aided in the death of almost five percent of their compatriots and blackened the reputation of Hungary (13-15).

Does it require further proof that the aim of the volume was not falsifying history and exonerating the collaborators of Nazi Germany?

It is hair-splitting to count how many German soldiers were present in Hungary at various moments of the occupation. To a serious historian it should be evident that the crime of the deportations could not and would not have taken place but for the military occupation of Hungary, which put an end to the two-year efforts of Kállay's government to leave the side of 
Jeszenszky, Géza. “The Controversy About 1944 in Hungary and the Escape of Budapest's Jews from Deportation. A Response." Hungarian Cultural Studies. e-Journal of the American Hungarian Educators Association, Volume 13 (2020) DOI: 10.5195/ahea.2020.388

Germany and conclude an armistice with the allied united nations. How many Soviet soldiers kept Hungary in the Soviet bloc? Maintaining a regime by terror does not require an enormous army.

Horthy must have suspected that Hitler's aim was the extermination of the Jews, as I pointed out in my Introduction by saying, "Could he believe that families with old people and children were just taken to Germany to work in fortifications and factories? Surely, he did not know exactly what went on at Auschwitz, but he should not have watched passively the systematic mass deportation of Hungarian citizens, starting on 15 May" (24). I also emphasized the Regent's responsibility for washing his hands like Pilate over the inhuman anti-Jewish decrees introduced by Hungary's Quisling government, followed by the ghettoization and the deportations of Hungarian citizens who expected protection from the head of state.

Pastor (and also Karsai) go out of their way to question whether Horthy demanded the stopping of the deportations at the crown council held on June 26. Yet it is Randolph Braham whom I quoted when reproducing Horthy's words, "I shall not tolerate this any further! I shall not permit the deportations to bring further shame on the Hungarians! Let the Government take measures for the removal of Baky and Endre! The deportation of the Jews of Budapest must cease! The Government must take the necessary steps!" (Braham 2000: 873.) Horthy had not the legal power to order the government to carry out any measure, but here comes Pastor's anti-hero, Colonel Koszorús, and his armored unit.

Whether State Secretary Baky really conspired in a coup d'etat to remove Horthy or this was only a rumor is of secondary importance; the three-thousand gendarmeries - planning and ready to carry out the rapid deportation of Budapest's Jews - who were illegally brought to Budapest were a fact. So was it also a fact that Horthy did give an order to Koszorús to force the gendarmerie to leave the capital. We do not know whether the colonel just blindly obeyed the commander-in-chief or also thought of the Jews facing immediate deportation. What mattered was the evacuation of the law-enforcement units who were under the direct authority of the Minister of the Interior and therefore of Baky. Without Horthy's decision to stop the deportations coupled with the carrying-out of this order by Koszorús, by mid-July all the Jews in Budapest would have ended in Auschwitz. Therefore, no historian can question the fact that the Jews living in Budapest were saved in July - at least until the October 15 coup by the Hungarian Arrow Cross led by Szálasi. Then the Hungarian rabble was released by the German Nazis to foil the armistice Horthy had concluded with the Soviets and already announced through the radio. In a recent essay of mine which appeared in the Hungarian journal, Magyar Szemle ['Hungarian Observer'] in January 2018 (Horthy és a magyar zsidók deportálása ['Horthy and the Deportation of the Hungarian Jews']) I did my best to give an impartial and honest answer to Horthy's responsibility, ending with the following statement: "Whether the (temporary) saving of over quarter-of-a-million Hungarian Jews counterbalances Horthy's partial responsibility in giving up a half million of his fellow-compatriots to the Germans, neither can a historian nor the administration of justice in this world settle."

Only malice can purport an aim to "minimize Hungary's war guilt" when, in fact, in my Introduction, I compare the passivity of the average Hungarian during the deportations (and let me add also watching the arrest of thousands of non-Jewish Hungarians suspected of pro-Ally sympathies) to a similar attitude during the communist terror: "Many Hungarians gave vent to their anti-Semitic prejudices and happily participated in stealing the properties of their deported 
Jeszenszky, Géza. “The Controversy About 1944 in Hungary and the Escape of Budapest's Jews from Deportation. A Response." Hungarian Cultural Studies. e-Journal of the American Hungarian Educators Association, Volume 13 (2020) DOI: 10.5195/ahea.2020.388

or hiding Jewish compatriots, while the majority of the population just watched the cruel removal of their Jewish neighbors passively. As when, a few years later, they were paralyzed with fear as the terror imposed by the communists raged, persecuting hundreds of thousands of innocents" (15).

As is well known, Franklin D. Roosevelt's envoy to Hungary, F.J. Montgomery, first called Hungary "the unwilling satellite." It is enough to substantiate this epithet by reading the Hungarian-American, journalist and historian Charles Fenyvesi's Három összeesküvés ['Three Conspiracies'], or numerous studies by György Ránki and Gyula Juhász, particularly the latter's collection of British documents (Juhász 1978), and his introduction to that in English (Juhász 1980), and of course my essay in the book under discussion, "Hungary in the Second World War: Tragic Blunders or Destiny?" to at least ponder if Hungary was really more than a reluctant ally of Nazi Germany.

Pastor, who can read the mind even of the deceased, asks, "Had Ránki lived past the 1989 regime change, would he not have revised his essay?" Pastor then adds that Ránki probably would not have offered his essay for this publication. Thirty-seven years after its first publication (in Hungarian), Ránki would certainly have revised it for a new book, but he, a true historian, would not have done it due to the 1989 political changes. Apparently, it is the good Pastor whose vision as a historian is marred by recent political developments in Hungary. Although it was my duty as editor to add a few notes to Ránki's essay in order to inform the reader about persons mentioned in the paper whose names are likely to have become unfamiliar today, it was indicated that these additions came from the editor. However, nowhere did I, as Pastor claims, take "issue with the dead Ránki." It is true that Ránki's essay dealt with Hungarian-German relations starting in 1933, but only as the antecedents to the war period, so I did not mislead anyone by writing that the essay "is a summary of Hungary's conduct during the Second World War" (32).

Pastor's comments on my essay, which focuses on the serious blunders committed by Hungary's leaders leading to participation in Hitler's war, attempt to question my whole approach even though his many quotes rather confirm my highly critical remarks. Any unbiased reader of my contributions to the present volume (Pastor is clearly not such) would see how far I am from using history for political purposes and that I am an opponent of national or religious prejudices. Contrary to Pastor's assumption, I strongly disagree with those who think that the 1919 Hungarian Soviet Republic was a Jewish affair and therefore justified subsequent antiJewish measures. It is simply a stupid assumption that I "grieve for the Horthy regime." I leave it to the hoped-for readers to decide if my forty-page long piece sounds fair or faulty. Let me just mention one point which reveals Pastor's inexplicable opposition to all actions of interwar Hungary. Pastor questions Hungary's sincerity that it wanted to revise Hungary's post-Trianon borders by peaceful means. His "proof" is that in 1921 it was the armed action of Hungarian free-troopers which led to a plebiscite that kept the town of Sopron and its vicinity within the borders of "rump" Hungary. Yet Hungary's interwar leaders were not irresponsible fools dreaming of armed action against the neighbors whose armed forces sixteen times outnumbered Hungary's. Pastor's other argument is that the return of Subcarpathia and a railway on Slovakinhabited territory in 1939 was achieved by military action. Apart from the fact that fighting in that action and losses were minimal, both Britain and the United States preferred those territories under Hungarian rather than pro-Nazi Slovak control, and that could be achieved only by occupying the territory. 
Jeszenszky, Géza. “The Controversy About 1944 in Hungary and the Escape of Budapest's Jews from Deportation. A Response." Hungarian Cultural Studies. e-Journal of the American Hungarian Educators Association, Volume 13 (2020) DOI: 10.5195/ahea.2020.388

The rest of the so-called review by Pastor, when discussing the other studies appearing in the book, also uses selected and sometimes distorted sentences from the various authors to undermine their credibility. Pastor has one strange aim: to make the gloomy record of Hungary in the Second World War look even poorer, disregarding the fact that in Hitler's Europe it was only the Poles (and for a while the French, the Belgians, the Dutch, and the Norwegians, all victims of attack by the Wehrmacht) who put up military resistance, and what went on in occupied Poland was a warning for the other countries about the consequences of standing up to the Nazi state, rather than an encouragement to follow the example. It does not reduce Horthy's responsibility that compared to the other satellite leaders the Hungarian head of state stands out as far from being servile in the talks with Hitler, as testified in the documents originally edited by a German historian (Hillgruber 1967), and brought out in Hungarian with a detailed, exemplary introduction by Ránki (1983). That publication shows that Central and Eastern Europe indeed faced terrible alternatives between 1938 and 1944, and it was not possible to escape a horrible fate. Unlike Slovakia and Romania, Hungary still tried to keep its contribution to the German war effort as limited as possible. A true historian should present that Hitler could rely on Romania and Slovakia, and even on a fraction of the Serbs, all owing so much to France and Britain, in serving his aims, and even plucky little Finland joined the war against the Soviet Union. Hungary's conduct should be studied in a comparative way.

For me it is inexplicable what drove Pastor to mislead his readers to such an extent about a book which tried to provide a balanced picture of how the Jews in Budapest escaped deportation and almost certain death in July 1944. The book is not a history of Hungarian antiSemitism, but rather provides the background to the foiled attempt to annihilate a section of the population in the capital of Hungary. While it does not try to exonerate the Hungarians from any ill deed, neither does it want - unlike the reviewer - to burden Hungary and the Hungarians with collective guilt. While many Hungarians deplore and condemn any barbarity committed by Hungarians (and, sadly, by so many others), we must hold up the example of those who tried to mitigate the disaster in 1944. The thousand Righteous Hungarians and the heroism of Raoul Wallenberg should also be given due recognition.

I sincerely hope that the readers of this journal will see that Pastor was directed not by professionalism, a dedication to historical truth, but by malice and personal bias.

\section{Works Cited}

Braham, Randolph L. 1981. The Politics of Genocide: The Holocaust in Hungary. New York: Columbia UP.

Braham, Randolph L. 2000. The Politics of Genocide: The Holocaust in Hungary, Condensed Edition. Detroit: Wayne State UP.

Fenyvesi, Charles. 2007. Három összeesküvés. Rundstedt tábornagy, Canaris tengernagy és a zsidó mérnök, aki megmenthette volna Európát ['Three Conspiracies: Field-Marshal Rundstedt, Admiral Canaris and the Jewish Engineer Who Could Have Saved Europe']. Budapest: Európa Kiadó.

Hillgruber, Andreas.1967. Staatsmänner und Diplomaten bei Hitler. Vertrauliche Aufzeichnungen über Unterredungen mit Vertretern des Auslandes 1939-1941 ['Statesmen 
Jeszenszky, Géza. "The Controversy About 1944 in Hungary and the Escape of Budapest's Jews from Deportation. A Response." Hungarian Cultural Studies. e-Journal of the American Hungarian Educators Association, Volume 13 (2020) DOI: 10.5195/ahea.2020.388

and Diplomats with Hitler: Confidential Records of Interviews With Foreign Representatives, 1939-1941']. Frankfurt am Main: Bernard \& Graefe Verlag für Wehrwesen.

Juhász, Gyula. 1978. Magyar-brit titkos tárgyalások 1943-ban ['Hungarian-British Secret Negotiations in 1943']. Budapest: Kossuth Kiadó.

Juhász, Gyula. 1980. "The Hungarian Peace-Feelers and the Allies in 1943". Acta Historica Academiae Scientiarum Hungaricae 3-4: 345-377.

Montgomery, John Flournoy. 1947. Hungary, the Unwilling Satellite. New York: Devin-Adair; repr. Morristown, NJ: Vista Books, 1993.

Ránki, György. 1983. Hitler hatvannyolc tárgyalása 1939-1944. Hitler Adolf tárgyalásai keleteurópai államférfiakkal ['Hitler's Sixty-Eight Exchanges with East-European Statesmen']. Budapest: Magvető Kiadó. 